\title{
Antiulcer, wound healing and hepatoprotective activities of the seaweeds Gracilaria crassa, Turbinaria ornata and Laurencia papillosa from the southeast coast of India
}

\author{
Kulandhaisamy Arul Senthil ${ }^{1}$, Annappan Murugan,,* \\ ${ }^{1}$ Department of Biochemistry and Biotechnology, Sri Nagalakshmi Ammal College of Sciences, \\ Pappunayakkanpatti, Madurai, Tamil Nadu, India, ${ }^{2}$ AnnMoo Agro Bio Aqua Technologies, Tuticorin, India
}

\begin{abstract}
Seaweeds have bioactive compounds of interest in the pharmaceutical industry. In India, seaweeds are used exclusively for phycocolloids production and have not yet received consideration as a dietary supplement. So, it has become imperative to explore the biomedical potential of seaweeds and promote their utilization as a functional food. The seaweeds Turbinaria ornata, Gracillaria crassa and Laurencia papillosa, collected from the Tuticorin coast of the Southeast coast of India and selected based on preliminary screening, were extracted with acetone and evaluated for antiulcer, wound healing and hepatoprotective activities. L. papillosa showed the highest level of gastric protection activity (81\%) at $200 \mathrm{mg} / \mathrm{kg}$, comparable to the standard drug ranitidine (90\%). G. crassa followed with $76 \%$. G. crassa and L. papillosa, showed marked wound-healing activity. G. crassa at $200 \mathrm{mg} / \mathrm{kg}$, showed a marked effect on the serum marker enzymes indicating prominent hepatoprotective activity. The noteworthy wound-healing and hepato-protective properties of G. crassa besides anti-ulcer activity next to L. papillosa were indicative of its potential for further consideration.
\end{abstract}

Uniterms: Seaweed/biomedical potential. Seaweed/antiulcer activity. Seaweed/wound-healing. Seaweed/ hepatoprotective activity. Gracilaria crassa/biomedical potential. Turbinaria ornata/biomedical potential. Laurencia papillosa/biomedical potential.

Algas marinhas possuem compostos bioativos de interesse para a indústria farmacêutica. Na Índia, as algas marinhas são usadas exclusivamente para a produção de ficocolóides e ainda não receberam a consideração como um suplemento dietético. Assim, tornou-se imperativo explorar o potencial biomédico de algas e promover a sua utilização como alimento funcional. As algas marinhas Turbinaria ornata, Gracillaria crassa e Laurencia papillosa, coletadas de Tuticorin, na costa sudeste da Índia, e selecionadas com base em triagem preliminar, foram extraídas com acetona e avaliadas quanto à atividade antiúlcera, de cicatrização de feridas e de hepatoproteção. L. papillosa mostrou o mais alto nível da atividade de proteção gástrica (81\%) na dose de $200 \mathrm{mg} / \mathrm{kg}$, comparável ao fármaco padrão, ranitidina (90\%). G. crassa mostrou atividade de $76 \%$. G. crassa e L. papillosa mostrou atividade martcante na cicatrização de feridas. G. Crassa, a $200 \mathrm{mg} / \mathrm{kg}$, mostrou efeito alto sobre o marcador sérico das enzimas, indicando atividade hepatoprotetora proeminente. A notável cura de feridas e as propriedades hepatoprotetoras de G. Crassa, além da atividade antiúlcera, próxima da L. Papillosa, foram indicativos do seu potencial para uma análise mais aprofundada.

Unitermos: Algas marinhas/potencial biomédico. Algas marinhas/atividade antiúlcera. Algas marinhas/ cicatrização de feridas. Algas marinhas/atividade hepatoprotetora. Gracilaria crassa/potencial biomédico. Turbinaria ornata/potencial biomédico. Laurencia papillosa/potencial biomédico.

\footnotetext{
*Correspondence: A. Murugan. AnnMoo Agro Bio Aqua Technologies. 44-Bryant Nagar $1^{\text {st }}$ Street East, Tuticorin - 628 008, India. E-mail: muruganrsa@gmail.com
} 


\section{INTRODUCTION}

Traditionally, plants and terrestrial microorganisms have been the focus of the search for new drug leads. The chemical novelty associated with such natural products offer great scope, as scientists are on the lookout for novel drug leads to combat the increasing incidence of infectious diseases and the development of resistance to existing pharmaceuticals. In this context, marine organisms such as bacteria, fungi, algae, sponges, soft corals, tunicates, molluscs and bryozoans have been shown to be the potential sources of novel and biologically active natural compounds with numerous pharmacological potentialities (Faulkner, 2000). Among them, the seaweeds, that produce a wide range of secondary metabolites with broadspectrum bioactivity, have immense biomedical potential (reviewed by Smit, 2004; El Gamal, 2010) and has been used in folk medicine for a variety of remedial purposes such as in eczema, gallstone, gout, scrofula, cooling agent for fever, menstrual trouble, renal problems, scabies (Hoppe, 1979).

A wide range of antibiotic, anti-HIV, anticoagulant, anticonvulsant, anti-inflammatory (Dang et al., 2008), antineoplastic, wound healing, antiulcer (Nagaoka et al., 2000), hepatoprotective (Mosaad et al., 2006) and antitumor activities for seaweed derived compounds have been reported (Lincoln et al., 1991). Seaweeds also assumed greater significance as they are rich sources of various types of antioxidant compounds (Kuda et al., 2005). The lower prevalence of breast and prostate cancer in Japan and China has been linked directly to seaweeds that are consumed in appreciable quantities in these countries than in North America and Europe (Pisani et al., 2002).

The distinctive seaweed resources of the Gulf of Mannar, Southeast coast of India are mainly used in the production of phycocolloids. The biomedical and nutritional potential of the seaweeds has not received much attention. So, the seaweeds Turbinaria ornata, Gracillaria crassa and Laurencia papillosa, selected based on preliminary screening (data not shown), were evaluated for pharmacological activities such as antiulcer, wound healing and hepatoprotective activities.

\section{MATERIAL AND METHODS}

\section{Extraction of seaweed}

The seaweeds Turbinaria ornata W.R. Taylor, 1964 (Phaeophyta: Phaeophyceae: Fucales: Sargassaceae), Gracillaria crassa Harvey ex J. Agardh 1876 (Rhodophyta: Florideophyceae: Gracilariales:
Gracilariaceae) and Laurencia papillosa (C. Agardh) Greville 1830 (Rhodophyta: Florideophyceae: Ceramiales: Rhodomelaceae), collected fresh from the Tuticorin coast (Lat. $8^{\circ} 45^{\prime} \mathrm{N}^{\prime}$ long. $78^{\circ} 10^{\prime} \mathrm{E}$ ) off the Southeast coast of India, were washed thoroughly to remove the adherents and air dried in the shade for $24 \mathrm{~h}$. About $100 \mathrm{gms}$ of each seaweed was macerated and extracted with $250 \mathrm{~mL}$ of acetone. Acetone was used based on the preliminary screening activity profile (data not shown). The extracts were cold steeped overnight at $-18{ }^{\circ} \mathrm{C}$ filtered with Whatman No.1 filter paper, evaporated, concentrated (Becerro et al., 1994; Riguera, 1997) and used in pharmacological screening. The yield of extraction was $2.95 \mathrm{~g}, 6.34 \mathrm{~g}$ and $4.68 \mathrm{~g}$ for T. ornata, G. crassa and L. papillosa respectively. The dosage of these extracts was chosen at random based on preliminary screening (data not shown).

\section{Experimental animals}

Healthy adult Wistar albino rats of both sexes, weighing 100 to $200 \mathrm{~g}$, were used in the experiment. The animals were acclimatized to laboratory conditions of temperature, humidity $(60 \pm 5 \%), 12 \mathrm{~h}$ light-dark cycles and fed with standard pellet diet and water ad libitum and the principles of laboratory animal care were followed. The animals were fasted for $16 \mathrm{~h}$, and were provided with water alone before the commencement of experiments. The experiments were carried out in the Department of Pharmacology, S.B. College of Pharmacy, Sivakasi and the necessary permission for the experiments was obtained from institutional ethics committee (Approval No. IAEC/ CPCSEA/SBCP/2006-2007/06).

\section{Antiulcer activity}

In the antiulcer assay (Shay et al., 1945; Suzuki et $a l ., 1976)$, the albino rats were divided into eight groups of four individuals each. The Group I received normal saline and served as negative control. Group II received $50 \mathrm{mg} / \mathrm{kg}$ p.o. of ranitidine as standard drug. Group III and IV received a Turbinaria ornata extract, Group V and Group VI were given Gracilaria crassa extract and Group VII and VIII were treated with Laurencia papillosa extract, dissolved in normal saline, at a dosage of 100 and $200 \mathrm{mg} / \mathrm{kg}$ p.o. All the animals received test extracts daily for three days and on the fourth day, a midline incision was made under anesthesia with ether and the stomach was exposed for pylorus ligation (Shay et al., 1945). The abdominal opening was closed by suture and the rat was not allowed to sleep. 
The animals were deprived of water during the postoperative period and were sacrificed after $4 \mathrm{~h}$. The stomach was carefully dissected out and gastric juice was collected and centrifuged at $3000 \mathrm{rpm}$ for 30 minutes. The total volume of gastric juice, its $\mathrm{pH}$, free and total acidity of gastric secretion, sodium and potassium ion concentration in gastric juice were estimated. The free and total acidities of the supernatant were calculated by titration with $0.1 \mathrm{~N}$ $\mathrm{NaOH}$ (Kulkarni, 1999). The stomach was incised along the greater curvature and pinned on a soft wooden board for evaluation of the ulcerated area and the ulcer index in the glandular stomach region was measured as Normal colored stomach-0, Red colouration- 0.5 , Spot ulcers-1, Haemorrhagic streaks-1.5, Surface ulcer-2, Deep ulcer-3, Perforation-4 and the mean ulcer score for each animal were expressed as ulcer index (Ganguli, Bhatnagar, 1973).

The percentage of ulcer inhibition was calculated by the following formula:

Control mean ulcer index - Test mean ulcer index Control mean ulcer index

\section{Wound healing activity}

Eight groups of Wistar albino rats, with four animals in each group, were anesthetized with ether and the animals were depilated on the back. One excision wound was inflicted by cutting away a $500 \mathrm{~mm}^{2}$ full thickness of skin from the depilated area. Then, this wound was undressed to the open environment. A commercial simple ointment [Hittboss $50 \mathrm{~g}$ (wool fat: $2.5 \mathrm{~g}$, hard paraffin: $2.5 \mathrm{~g}$, cetostearyl alcohol: $2.5 \mathrm{~g}$, white soft paraffin: $42.5 \mathrm{~g}$ )] was formulated with 100 and $200 \mathrm{mg} / \mathrm{kg}$ of the seaweed Turbinaria ornata, Gracilaria crassa and Laurencia papillosa extracts. Seaweed extracts were prepared with 5\% w/w ointment. Group I, the control, received a simple ointment base and the Group II was treated with standard povidone iodine ointment $(5 \% \mathrm{w} / \mathrm{w})$.

The test ointment of Turbinaria ornata was applied to Group III and IV animals and Group V and VI were treated with Gracilaria crassa ointment and Group VII and VIII with Laurencia papillosa based ointment. All the wounds in rats were traced using graph paper on the day of wounding. Then the standard drug and test ointments were applied daily till the wound was completely healed. The progressive changes in wound area were monitored planimetrically by tracing the wound margin on graph paper every alternate day, which gave an indication of the rate of wound healing activity. The number of days required for healing of the wound was determined (Chatterjee, Chakaravorty, 1993).

\section{Hepatoprotective activity}

Thirty six albino rats were randomly divided into nine groups consisting of four animals each. The Group I, which served as non-intoxicated control, was treated with normal saline. Liver damage was induced in other groups of animals by orally treating with rifampicin $(1000 \mathrm{mg} / \mathrm{kg})$. The Group II served as intoxicated control and received no test extracts. The Group III received standard drug silymarin at $100 \mathrm{mg} / \mathrm{kg}$ and Groups IV and $\mathrm{V}$ received a Turbinaria ornata extract at 100 and $200 \mathrm{mg} / \mathrm{kg}$, p.o. The Groups VI and VII animals were treated with Gracilaria crassa extracts and Groups VIII and Group IX animals Laurencia papillosa extract at a dose level of 100 and $200 \mathrm{mg} / \mathrm{kg}$ p.o respectively. All the test seaweed extracts, dissolved in normal saline, and silymarin were administered four times with $12 \mathrm{~h}$ intervals. After $48 \mathrm{~h}$ of Rifampicin administration, blood was collected from all the groups of animals by puncturing retro orbital plexus after anesthetizing with chloroform. The blood samples were allowed to clot for 45 minutes at room temperature and the serum was separated by centrifugation at $2500 \mathrm{rpm}$ at $37^{\circ} \mathrm{C}$ for $10 \mathrm{~min}$ for the assessment of biochemical parameters of serum glutamic oxaloacetic transaminase (SGOT), serum glutamic pyruvic transaminase (SGPT) and alkaline phosphatase, direct and indirect and total bilirubin (Kurma, Mishra, 1997).

\section{Statistical analysis}

The values were expressed as mean \pm SD of four replicates for each experiment. Student's t-test indicated the significance of the experimental results compared to control and $\mathrm{P}<0.05$ was considered as significant.

\section{RESULTS}

When compared to the Group I negative control, almost all the three extracts showed antiulcer activity (Figure 1 and Table I). The acetone extract of Gracilaria crassa and Laurencia papillosa significantly reduced the total volume of gastric juice, free and total acidity of gastric secretion and $\mathrm{Na}^{+}$content of gastric juice at 200 $\mathrm{mg} / \mathrm{kg}$ concentration. The increase in $\mathrm{pH}$ level and $\mathrm{K}^{+}$ content indicated the good antiulcer activity against gastric pyloric ulcers in rats. The percentage of antiulcer activity of seaweed L. papillosa and G. crassa at $200 \mathrm{mg} / \mathrm{kg}$ were comparable to the performance of the standard drug Ranitidine. When compared to control, the activity of both the extracts was significant $(\mathrm{P}<0.05)$, except that of K value of G. crassa at $100 \mathrm{mg} / \mathrm{kg}$. Though T. ornata 

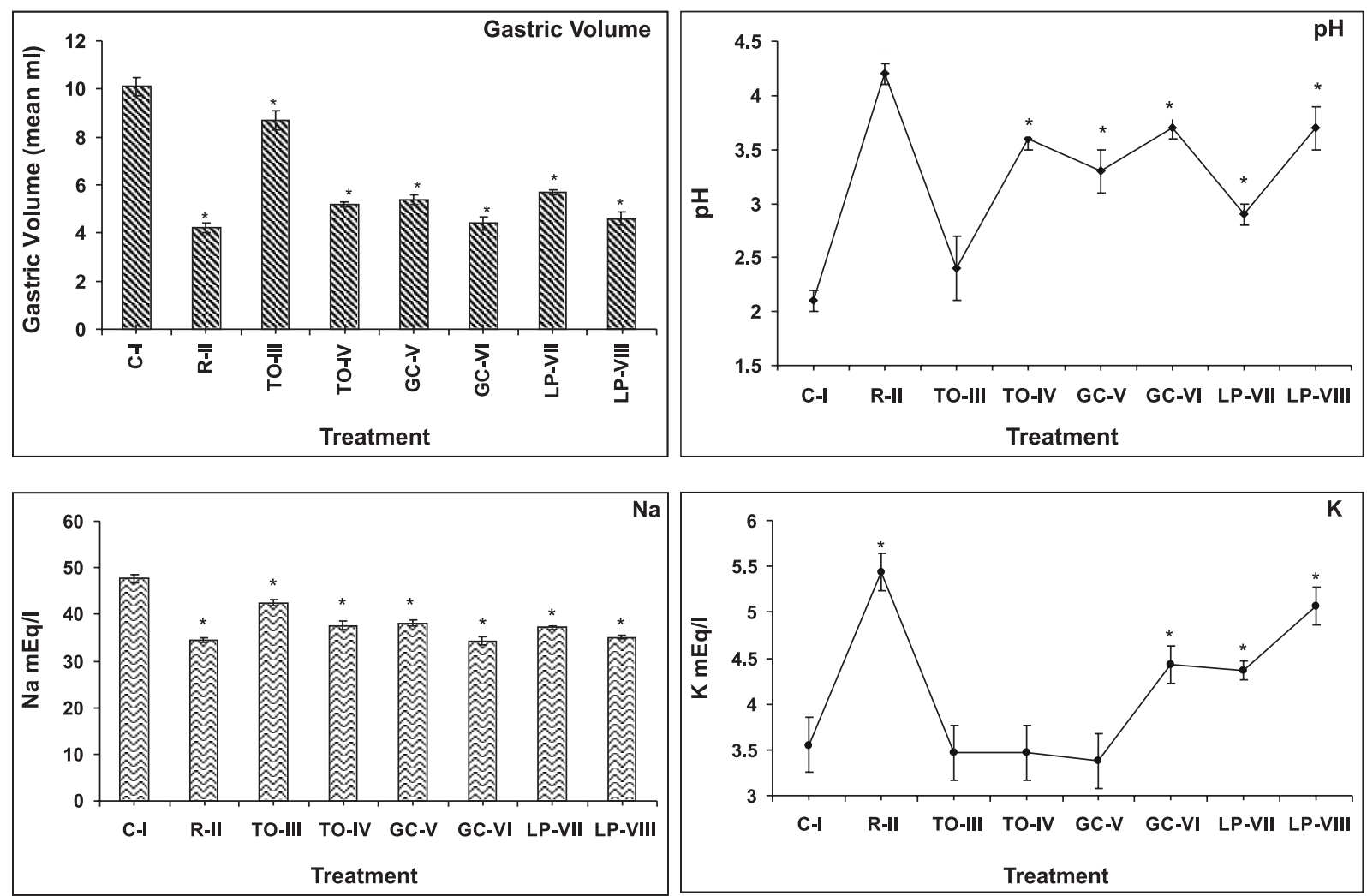

FIGURE 1 - Antiulcer activity of acetone extract of seaweed Turbinaria ornata, Gracilaria crassa and Laurencia papillosa against pylorus ligation induced gastric ulcer: Gastric Volume, $\mathrm{pH}, \mathrm{Na}$ and $\mathrm{K}$ (Values: mean $\pm \mathrm{SD}$ of four replicates; ${ }^{*} \mathrm{P}<0.05$ compared to control; C-Control; R-Ranitidine; TO-Turbinaria ornata; GC-Gracilaria crassa; LP-Laurencia papillosa; I-VIII - Animal Groups; R-II-50 mg/kg; TO-III, GC-V \& LP-VII -100 mg/kg; TO-IV, GC-VI \& LP-VIII-200 mg/kg).

TABLE I - Antiulcer activity of acetone extract of seaweed Turbinaria ornata, Gracilaria crassa and Laurencia papillosa against pylorus ligation induced gastric ulcer: Acidity, Ulcer score and \% of Ulcer inhibition

\begin{tabular}{lcccccc}
\hline Treatment & Group & $\begin{array}{c}\text { Dose } \\
(\mathrm{mg} / \mathrm{kg})\end{array}$ & $\begin{array}{c}\text { Free acidity } \\
\mathrm{mEq} / \mathrm{L}\end{array}$ & $\begin{array}{c}\text { Total acidity } \\
\mathrm{mEq} / \mathrm{L}\end{array}$ & Ulcer score & $\begin{array}{c}\text { \% of ulcer } \\
\text { inhibition }\end{array}$ \\
\hline Control & I & - & $19.22 \pm 0.6$ & $47.42 \pm 2.7$ & $2.57 \pm 0.3$ & - \\
Ranitidine & II & 50 & $7.67 \pm 0.4^{*}$ & $22.24 \pm 1.0^{*}$ & $0.25 \pm 0.3^{*}$ & 90.27 \\
Turbinaria ornata & III & 100 & $17.78 \pm 0.4^{*}$ & $41.92 \pm 0.5^{*}$ & $1.75 \pm 0.3^{*}$ & 31.91 \\
& IV & 200 & $13.82 \pm 0.7^{*}$ & $36.59 \pm 0.5^{*}$ & $1.12 \pm 0.3^{*}$ & 56.42 \\
Gracilaria crassa & V & 100 & $14.41 \pm 0.5^{*}$ & $36.41 \pm 0.8^{*}$ & $1.25 \pm 0.3^{*}$ & 51.36 \\
& VI & 200 & $8.39 \pm 0.8^{*}$ & $23.12 \pm 1.3^{*}$ & $0.62 \pm 0.3^{*}$ & 75.88 \\
Laurencia papillosa & VII & 100 & $11.57 \pm 0.4^{*}$ & $25.15 \pm 1.1^{*}$ & $0.75 \pm 0.3^{*}$ & 70.82 \\
& VIII & 200 & $7.11 \pm 0.1^{*}$ & $20.70 \pm 0.4^{*}$ & $0.5 \pm 0.3^{*}$ & 80.55 \\
\hline
\end{tabular}

(values: mean $\pm \mathrm{SD}$ of four replicates) $(* \mathrm{P}<0.05$ compared to control)

showed good activity, it was low when compared to the other two seaweeds. The results indicated the highest level of gastric protection activity by L. papillosa extract at all concentrations.

G. crassa and L. papillosa, showed marked wound-healing activity when compared to that of the reference standard and a control group of albino rats (Figure 2). The wound healing activity of the G. crassa extract at the concentration of $200 \mathrm{mg} / \mathrm{kg}$ $\left(249 \pm 0.8 \mathrm{~mm}^{2}\right)$ was comparable with that of standard ointment $\left(243 \pm 1.7 \mathrm{~mm}^{2}\right)$ on the 6th day of the experiment. The reduction in wound area was significant in rats treated with G. crassa $\left(9 \pm 6.3 \mathrm{~mm}^{2}\right)$ and L. papillosa $\left(10 \pm 2.5 \mathrm{~mm}^{2}\right)$ at the concentration of $200 \mathrm{mg} / \mathrm{kg}$ when 

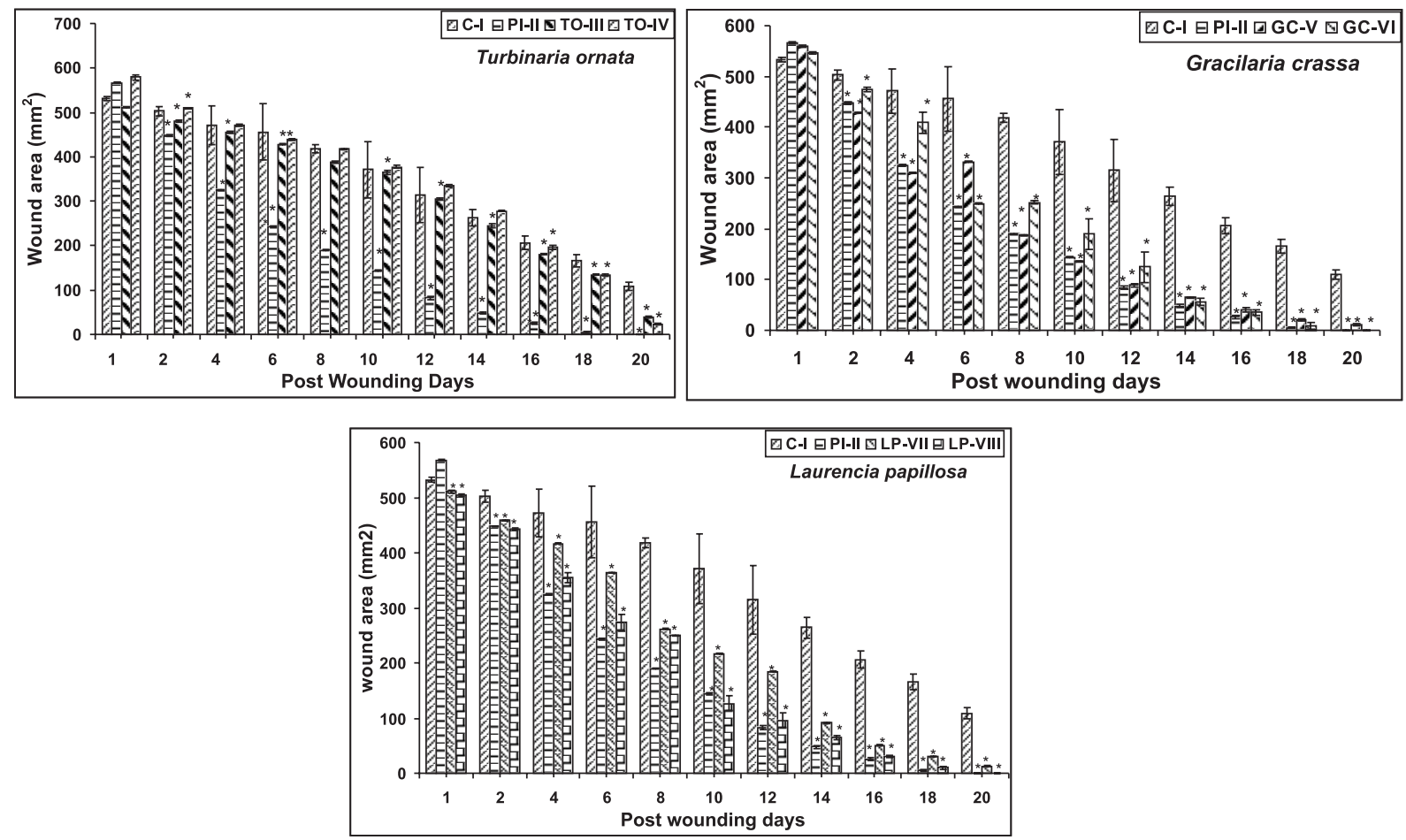

FIGURE 2 - Wound healing activity of seaweed Turbinaria ornata, Gracilaria crassa and Laurencia papillosa acetone extracts. (Values: mean $\pm \mathrm{SD}$ of four replicates; ${ }^{*} \mathrm{P}<0.05$ compared to control; C-Control; PI-Povidone Iodine ointment $(5 \% \mathrm{w} / \mathrm{w})$; TOTurbinaria ornata; GC-Gracilaria crassa; LP-Laurencia papillosa; I-VIII - animal groups; TO-III, GC-V, LP-VII-100 mg/kg; TO-IV, GC-VI, LP-VIII-200 mg/kg).

compared to the positive control group of animals $\left(5 \pm 1.6 \mathrm{~mm}^{2}\right)$ on the $18^{\text {th }}$ day and on the $20^{\text {th }}$ day, the two extracts at the same concentration showed complete healing in comparison with standard drug. The T. ornata extract exhibited lowest reduction in the wound area at both concentrations when compared to standard drug on the $20^{\text {th }}$ day. The activities of all extracts were significant $(\mathrm{P}<0.05)$ when compared to control.

In the hepatoprotective activity assay, there was a significant increase in serum GOT, GPT, ALP and bilirubin levels in toxicated Group II than the normal control Group I (Figure 3 and Table II) and the seaweed extracts showed reduction in their elevated levels.

G. crassa showed a marked effect on the serum marker enzymes at $200 \mathrm{mg} / \mathrm{kg}$ dose when compared to that of standard drug, indicating the prominent hepatoprotective activity. The SGPT level was prominently reduced by all extract concentrations than that by standard drug (Group III). The L. papillosa $(200 \mathrm{mg} / \mathrm{kg})$ reduced the level of bilirubin equal to that of the standard drug and T. ornata showed equivalent activity to that of the standard drug in the reduction of direct bilirubin. The activities of the extracts were dose dependent and significant $(\mathrm{P}<0.05)$ when compared to negative control Rifampicin.

\section{DISCUSSION}

G. crassa possesses alkaloids, flavonoids, saponins, tannins and cardiac glycosides (Jeyaseelan et al., 2012). The higher percentage of antiulcer activity observed in $L$. papillosa and G. crassa against gastric and pyloric ulcers in rats could be due to the terpenoid compounds (Kuniyoshi et al., 2005) as terpenoid compounds are effective antiulcer agents because they protect the mucosa from the acid effects by selectively inhibiting prostaglandin PGF2 (Aguwa, Okunji, 1986). The report that Gracilaria spp. has been used in the treatment of stomach disorders (Trono, 1999) and the usefulness of carrageenan in ulcer therapy (De Almeida et al., 2011), substantiated the antiulcer activity of G. crassa in the present study. Also, the sulfated algal polysaccharides (Silva et al., 2011) in the seaweeds may provide an effective protection against gastric damage. The fats play a buffering role in reducing and neutralizing the gastric juice and the reported presence of fatty acids in antiulcer compounds isolated from $G$. verrucosa (Sakagami et al., 1992) substantiated the anti-ulcer activity in $G$. crassa. And, the presence of polyunsaturated fatty acids in Gracilaria species (Vasanthi et al., 2012), the precursors of prostaglandins, which increase the mucosal resistance, 

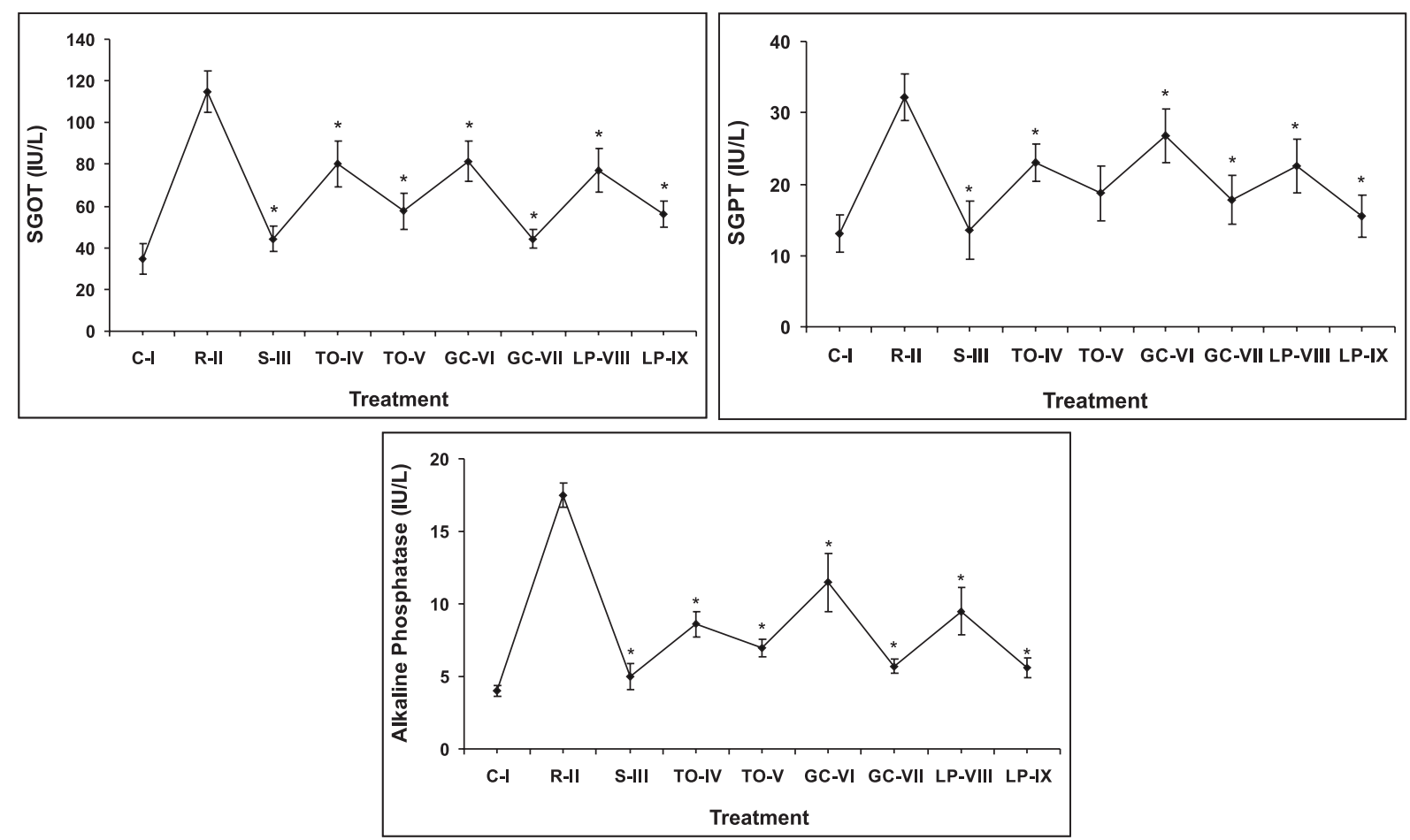

FIGURE 3 - Hepatoprotective activity of seaweed Turbinaria ornata, Gracilaria crassa and Laurencia papillosa acetone extracts: SGOT, SGPT and alkaline phosphatase. (Values: mean \pm SD of four replicates; ${ }^{*} \mathrm{P}<0.05$ compared to Rifampicin group; C-Control; R-Rifampicin-1000 mg/kg; S-Silymarin-100 mg/kg; TO-Turbinaria ornata; GC-Gracilaria crassa; LP-Laurencia papillosa; I-IXGroup of animals; TO-IV, GC-VI, LP-VIII - 100 mg/kg; TO-V, GC-VII, LP-IX-200 mg/kg).

TABLE II - Hepatoprotective activity of seaweed Turbinaria ornata, Gracilaria crassa and Laurencia papillosa acetone extracts

\begin{tabular}{lccccc}
\hline Treatment & Group & $\begin{array}{c}\text { Dose } \\
(\mathrm{mg} / \mathrm{kg})\end{array}$ & $\begin{array}{c}\text { Bilirubin Direct } \\
(\mathrm{mg} / \mathrm{dL})\end{array}$ & $\begin{array}{c}\text { Bilirubin Indirect } \\
(\mathrm{mg} / \mathrm{dL})\end{array}$ & $\begin{array}{c}\text { Bilirubin } \\
(\mathrm{mg} / \mathrm{dL})\end{array}$ \\
\hline Control & I & -- & $0.5 \pm 0.1$ & $1 \pm 0.3$ & $1.6 \pm 0.3$ \\
Rifampicin & II & 1000 & $1.8 \pm 0.3$ & $3.7 \pm 0.6$ & $5.6 \pm 0.9$ \\
Silymarin & III & 100 & $0.6 \pm 0.2^{*}$ & $0.9 \pm 0.1^{*}$ & $2.0 \pm 0.3^{*}$ \\
Turbinaria ornata & IV & 100 & $1.1 \pm 0.2^{*}$ & $1.9 \pm 0.2^{*}$ & $4.0 \pm 0.8^{*}$ \\
& V & 200 & $0.5 \pm 0.2^{*}$ & $1.3 \pm 0.3^{*}$ & $2.3 \pm 0.4^{*}$ \\
Gracilaria crassa & VI & 100 & $1.6 \pm 0.2$ & $2.0 \pm 0.2^{*}$ & $3.9 \pm 0.7^{*}$ \\
& VII & 200 & $0.8 \pm 0.1^{*}$ & $1.3 \pm 0.2^{*}$ & $2.1 \pm 0.3^{*}$ \\
Laurencia papillosa & VIII & 100 & $1.0 \pm 0.3^{*}$ & $1.9 \pm 0.2^{*}$ & $3.0 \pm 0.4^{*}$ \\
& IX & 200 & $0.6 \pm 0.2^{*}$ & $1.1 \pm 0.3^{*}$ & $1.7 \pm 0.3^{*}$ \\
\hline
\end{tabular}

(values: mean $\pm \mathrm{SD}$ of four replicates) $(* \mathrm{P}<0.05$ compared to rifampicin group)

might be the responsible factor for anti-ulcer activity of $G$. crassa.

The oxygen-derived free radicals play an important role in the pathogenesis of the injury to various tissues, including the digestive system (Boonchum et al., 2012). The species of the genus Gracilaria contain abundant amino acids, fatty acids, vitamins, minerals, polyphenolic compounds and carbohydrates (Marinho-Soriano, Bourret,
2005; Yangthong et al., 2009; De Almeida et al., 2011) which might play a role in the defense against oxidative tissue damage caused by ulceration in the stomach. The report on the health promoting properties of the genus Gracilaria seaweed extracts especially antioxidative properties (Ganesan et al., 2008; Yangthong et al., 2009; Vijayavel, Marinez, 2010; Souza et al., 2011) substantiated the observation in G. crassa. The fact that Gracilaria 
species possess anti-inflammatory compounds (Dang et al., 2008; Coura et al., 2011) adds value to antiulcer and wound healing activities in $G$. crassa.

Brown algae possesses polysaccharides fucoidan, laminaran, cellulose, alginates and mannitol and algal fucans, galactans and alginates have been shown to possess anticoagulant, anticancer and hypocholesterolemic activities (Lordan et al., 2011). Fucoidans are reported to have an effect on the inflammatory and immune systems (Pomin, Mourao, 2008) and laminarin has been identified as a modulator of intestinal metabolism through its effects on mucus composition, intestinal $\mathrm{pH}$ and short chain fatty acid production (Deville et al., 2007). The activity in $T$. ornata corresponds to the presence of polysaccharides with anti-ulcer activity (Shibata et al., 2003) and high phenolic levels with antioxidant and antibacterial activities (Zubia et al., 2008). The present study coincided with the report of Boonchum et al. (2012) that aqueous extract of T. conoides reduced gastric ulceration in the range of $50.98-99.85 \%$ at $500 \mathrm{mg} . \mathrm{kg}^{-1}$ dosage. Comparatively, in the present study, the observed activity at $200 \mathrm{mg} / \mathrm{kg}$ dosage was higher (56\%). The activity in $T$. ornata was further substantiated by the free radical scavenging property and anti-inflammatory potential (Ananthi et al., 2011). The cytoprotective nature of aqueous extract of the brown algae against gastric mucosal erosions has been substantiated with a near normal value of proteins (Balaji, Raghavendran et al., 2004). Also, the presence of halogenated and non halogenated terpenoids (Suzuki, Kurosawa, 1979) in the seaweeds could be attributed to their wound healing capacity. It could be deduced that a combination of factors mentioned above might be responsible for the untiulcer and wound healing activities of the three algae.

When the liver cells get damaged as a result of introduction of infectious agents or chemicals, the serum levels of GPT and GOT tend to increase significantly (Recknagel, 1967) as observed in the present study. Similarly, elevations of creatinine and bilirubin have been reported in the acetaminophen induced hepato-toxicity (Ellenhorn et al., 1997). The prominent activity in $G$. crassa at $200 \mathrm{mg} / \mathrm{kg}$ dosage was substantiated by similar elevated levels of total bilirubin, SGOT, SGPT, LDH and ALP in aflatoxin $\mathrm{B}_{1}$ intoxicated rats and restoration to normal level in the rats treated with aqueous extract (250 $\mathrm{mg} \mathrm{kg}^{-1}$ body weight) of marine algae G. corticata (Manoharan et al., 2008). The hepatoprotective activity reported in G. edulis against liver injury induced by D-Galactosamine/endotoxin in rats (Sathivel et al., 2003) holds good for the present observation.

The reported chemoprotective effect of $L$. obtusa and Caulerpa prolifera extracts, collected from the Egyptian coast of the Red Sea, against AFB1-initiated liver change in rats (Mosaad et al., 2006) substantiated the observed higher activity in L. papillosa. The hepatoprotective nature of the brown seaweeds Sargassum polycystem and that of Ecklonia stolonifera against acetaminophen induced hepatic damage in rats (Balaji Raghavendran et al., 2004) and tacrine-induced cytotoxicity in Hep G2 cells (Kim et al., 2005) holds well for the activity in T. ornata. The present observation of dose dependent activity in the three seaweed extracts coincided with the observation of Wong et al. (2000) in Myagropsis myagroides and Sargassum henslowianum.

Vijayabaskar and Shyamala (2011) reported a highest polyphenolic content of $43.72 \pm 1.63 \mathrm{mg}$ gallic acid equivalents (GAE)/g extract in $T$. ornata from Gulf of Mannar. Hence, the activity in T. ornata could be attributed to the polyphenolic derivatives (Zubia et al., 2008; Thomas, Kim, 2011). Also, in pharmaceutical field, alginates have been used to treat wounds and gastric ulcers for many years (Nagaoka et al., 2000). Calcium alginate has been reported to have both healing and preventive effects on $\mathrm{CCl}_{4}$ induced hepatotoxic damages in rats, suggesting that the ameliorative effects of calcium alginate may be related to its antioxidant properties (Khotimchenko, Khotimchenko, 2004) of brown seaweeds. It could be deduced that the compounds which give protection against liver plasma membrane alteration or promote cellular mitosis action for the repair of the liver cells (Wong et al., 2000) may be responsible for the hepatoprotective activity of the seaweeds.

Seaweeds produce compounds like carotenoids, terpenoids, xanthophylls, chlorophyll, vitamins, saturated and polyunsaturated fatty acids, amino acids, acetogenins, antioxidants such as polyphenols, alkaloids, halogenated compounds and polysaccharides such as agar, carrageenan, proteoglycans, alginate, laminaran, rhamnan sulfate, galactosyl glycerol and fucoidan (De Almeida et al., 2011) and hence, will be of immense help to humanity. The antiulcer activity in seaweeds assumes significance considering the fact that proton pump inhibitors and selective $\mathrm{H} 2$ receptor blockers, used in ulcer treatment, have side effects with $70 \%$ possibility of recurrence of stopping the same (Sachs et al., 2002). The review of the bioactive metabolites of alga belonging to the genus Gracilaria (De Almeida et al., 2011), the report that a Laurencia terpenoid extract from the red alga Laurencia tristicha could improve antioxidative and decrease DNA damage effectively and safe to be taken orally (Liang et al., 2007), the postulation that L. undulata could be used as adjuvant therapeutic materials for patients with bronchial asthma (Jung et al., 2009) and the fact that the 
brown algae (Phaeophyceae) has normally never been associated with toxin production and lack of signs of toxicity nor deaths when rats were administered with $5000 \mathrm{mg} / \mathrm{kg}^{-1}$ of the aqueous extract of $T$. conoides during 14 days of observation (Boonchum et al., 2012) implied that the three screened seaweeds in the present study could be of immense value in antiulcer, wound healing and hepatoprotective functionality.

\section{CONCLUSIONS}

The acetone extracts of seaweeds Gracilaria crassa, Laurencia papillosa and Turbinaria ornata showed antiulcer, wound healing and hepatoprotective activities. Among them, G. crassa was significant as it showed prominent and noteworthy wound healing and hepatoprotective activities besides showing good antiulcer activity next to Laurencia papillosa. G. crassa could be a potential candidate of biomedical importance.

\section{ACKNOWLEDGEMENTS}

The authors thank Suganthi Devadason Marine Research Institute, Tuticorin and Department of Pharmacology, S.B. College of Pharmacy, Sivakasi for facilities and support. The first author gratefully acknowledges the Science and Society Division of Department of Science and Technology, Govt. of India, New Delhi for fellowship through the seaweed project (SSD/WS/03/2001).

\section{REFERENCES}

ANANTHI, S.; GAYATHRI, V.; CHANDRONITHA, C.; LAKSHMISUNDARAM, R.; VASANTHI, H.R. Free radical scavenging and anti-inflammatory potential of a marine brown alga Turbinaria ornata (Turner) J. Agardh. Indian J. Mar. Sci., v.40, n.5, p.664-670, 2011.

AGUWA, C.N.; OKUNJI, C.O. Gastrointestinal studies of Pyrenacantha staudtzz leaf extracts. J. Ethnopharmacol., v.15, n.1, p.45-55, 1986.

BALAJI RAGHAVENDRAN, H.R.; SAKTHIVEL, A.; DEVAKI, T. Efficacy of brown seaweed hot water extract against $\mathrm{HCl}$-ethanol induced gastric mucosal injury in rats. Arch. Pharmacol. Res., v.27, n.4, p.449-453, 2004.

BECERRO, B.A.; LOPEZ, N.I.; TURON, X.; URIZ, M.J. Antimicrobial activity and surface bacterial film in marine sponges. J. Exp. Mar. Biol. Ecol., v.179, p.195-205, 1994.
BOONCHUM, W.; VACHARAPIYASOPHON, P.; K A N J A N A P O T H I, D .; P EKK O H, J .; A M O R N L ER D P I S O N, D .; P U M A S, C .; PEERAPORNPISAL, Y. Anti-gastric ulcer and acute oral toxicity of aqueous extract of Turbinaria conoides from the Gulf of Thailand. Chiang Mai J. Sci., v.39, n.2, p.292-299, 2012.

CHATTERJEE, T.K.; CHAKRAVORTY, A. Wound healing properties of the new antibiotics (MT81) in mice. Indian Drugs, v.30, n.9, p.450-452, 1993.

COURA, C.O.; DE ARAUJO, I.W.; VANDERLEI, E.S.; RODRIGUES, J.A.; QUINDERE, A.; FONTES, B.P.; DE QUEIROZ, I.N.; DE MENEZES, D.B.; BEZERRA, M.M.; E SILVER, A.A.; CHAVES, H.V.; JORGE, R.J; EVANGELISTA, J.S.; BENEVIDES, N.M. Antinociceptive and anti-inflammatory activities of sulphated polysaccharides from the red seaweed Gracilaria cornea. Basic Clin. Pharmacol. Toxicol., v.110, n.4, p.335-341, 2011.

DANG, H.T.; LEE, H.J.; YOO, E.S.; SHINDE, P.B.; LEE, Y.M.; HONG, J.; KIM, D.K.; JUNG, J.H. Antiinflammatory constituents of the red alga Gracilaria verrucosa and their synthetic analogues. J. Nat. Prod., v.71, n.2, p.232-240, 2008.

DE ALMEIDA, C.L.F.; FALCÃO, H.S.; LIMA, G.R.M.; MONTENEGRO, C.A.; LIRA, N.S.; ATHAYDEFILHO, P.F.; RODRIGUES, L.C.; DE SOUZA, M.F.V.; BARBOSA-FILHO, J.M.; BATISTA, L.M. Bioactivities from marine algae of the Genus gracilaria. Int. J. Mol. Sci., v.12, n.7, p.4550-4573, 2011.

DEVILLE, C.; GHARBI, M.; DANDRIFOSSE G.; PEULEN, O. Study on the effects of laminarin, a polysaccharide from seaweed, on gut characteristics. J. Sci. Food Agric., v.87, n.9, p.1717-1725, 2007.

EL GAMAL, A.A. Biological importance of marine algae. Saudi Pharm. J., v.18, n.1, p.1-25, 2010.

ELLENHORN, M.J.; BARCELOUX, D.G.; SCHONWALD, S. Acetaminophen. In: ELLENHORN, M.J., BARCELOUX, D.G., (Eds.). Ellenhorn's medical toxicology: diagnosis and treatment of human poisoning. 2.ed. Baltimore: Williams \& Wilkins, 1997. p.180-195.

FAULKNER, D.J. Marine natural products. Nat. Prod. Rep., v.17, n.1, p.1-55, 2000. 
GANESAN, P.; KUMAR, C.S.; BHASKAR, N. Antioxidant properties of methanol extract and its solvent fractions obtained from selected Indian red seaweeds. Bioresour. Technol., v.99, n.8, p.2717-2723, 2008.

GANGULY, A.K.; BHATNAGAR, O.P. Effect of bilateral adrenalectomy on production of restraint ulcers in the stomach of albino rats. Can. J. Physiol. Pharmacol., v.51, n.10, p.748-750, 1973.

HOPPE, H.A. Marine algae and their products and constituents in pharmacy. In: HOPPE, H.A.; LEVRING. T.; TANAKA, Y., (Eds.). Marine algae in pharmaceutical science. v.1. Berlin: Walter de Gruyter, 1979. p.25-119.

JEYASEELAN, E.C.; KOTHAI, S.; KAVITHA, R.; THARMILA S.; THAVARANJIT, A.C. Antibacterial activity of some selected algae present in the costal lines of Jaffna peninsula. Int. J. Pharm. Biol. Arch., v.3, n.2, p.352-356, 2012.

JUNG, W-K.; CHOI, I.; OH, S.; PARK, S-G.; SEO, S-K.; LEE, S-W.; LEE, D-S.; HEO, S-J.; JEON, Y-J.; J-YOUNG JE, F.; CHANG-BUM AHN, F.; JIN SOO KIM, G.; KWANG SOO OH, G.; KIM, Y-M.; MOON, C.; CHOI, I-W. Antiasthmatic effect of marine red alga (Laurencia undulata) polyphenolic extracts in a murine model of asthma. Food Chem. Toxicol., v.47, n.2, p.293-297, 2009.

KHOTIMCHENKO, Y.S.; KHOTIMCHENKO, M.Y. Healing and preventive effects of calcium alginate on carbon tetrachloride induced liver injury in rats. Mar. Drugs, v.2, n.3, p.108-122, 2004.

KIM, Y.C.; AN, R.B.; YOON, N.Y.; NAM, T.J.; CHOI, J.S. Hepatoprotective constituents of the edible brown alga Ecklonia stolonifera on tacrine-induced cytotoxicity in Hep G2 cells. Arch. Pharmacol. Res., v.28, n.12, p.1376-80, 2005.

KUDA, T.; TSUNEKAWA, M.; GOTO, H.; ARAKI, Y. Antioxidant properties of four edible algae harvested in the Noto Peninsula, Japan. J. Food Compos. Anal., v.18, n.7, p.625-633, 2005.

KULKARNI, A.R.; KULKARNI, V.H.; SHASTRY, C.S.; SATEESH, B.; KUKKERI, V.I.; MARIHAL, S.C. Screening of gulva leaves extracts for analgesic, anti inflammatory and antiulcer activity in albino rats. Indian Drugs, v.36, n.6, p.363-367, 1999.
KUNIYOSHI, M.; WAHOME, P.G.; MIONO, T.; HASHIMOTO, T.; YOKOYAMA, M.; SHRESTHA, K.L.; HIGA, T. Terpenoids from Laurencia luzonensis. J. Nat. Prod., v.68, n.9, p.1314-1317, 2005.

KURMA, S.R.; MISHRA, S.H. Hepatoprotective activity of the whole plant of Fumaria indica. Indian J. Pharm. Sci., v.59, n.4, p.165-170, 1997.

LIANG, H.; HE, J.; MA, A-G.; ZHANG, P-H.; BI, S-L.; SHI, D. Effect of ethanol extract of alga Laurencia supplementation on DNA oxidation and alkylation damage in mice. Asia Pac. J. Clin. Nutr., v.16, n.1, p.164-168, 2007.

LINCOLN, A.R.; STRUPINSKI, K.; WALKER, M.J. Bioactive compounds from algae. Life Chem. Rep., v.8, p.97-183, 1991.

LORDAN, S.; PAUL ROSS, R.; STANTON, C. Marine bioactives as functional food ingredients: potential to reduce the incidence of chronic diseases. Mar. Drugs, v.9, n.6, p.1056-1100, 2011.

MANOHARAN, N.; SAMPATHKUMAR, P.; DHEEBA, B.; SHEIKABDULLA, S.; VINOTHPRASANNA, G.; VINOTHKANNAN, R.; KALAVATHY, S.; VIJAYAANAND, A.; SHANMUGASUNDARAM, A. Potential hepatoprotective effect of aqueous extract of Gracilaria corticata in $\mathrm{AFB}_{1}$ induced hepatotoxicity in wistar rats. J. Biol. Sci., v.8, n.8, p.1352-1355, 2008.

MARINHO-SORIANO, E.; BOURRET, E. Polysaccharides from the red seaweed Gracilaria dura (Gracilariales, Rhodophyta). Bioresour. Technol., v.96, n.3, p.379-382, 2005.

MOSAAD, A.; WAHHAB, A.; HANAA, H.; MOHAMAD, A.; HAGAZI, M. Prevention of aflatoxin $\mathrm{B}_{1}$ - initiated hepatotoxicity in rat by marine algae extracts. J. Appl. Toxicol., v.26, n.3, p.229-238, 2006.

NAGAOKA, M.; SHIBATA, H.; KIMURA-TAKAGI, I. Antiulcer effects and biological activities of polysaccharides from marine algae. Biofactors, v.12, n.1-4, p.267-274, 2000.

PISANI, P.; BRAY, F.; PARKIN, D.M. Estimates of the world-wide prevalence of cancer for 25 sites in the adult population. Int. J. Cancer, v.97, n.1, p.72-81, 2002.

POMIN, V.H.; MOURAO, P.A.S. Structure, biology, evolution, and medical importance of sulfated fucans and galactans. Glycobiology, v.18, n.12, p.1016-1027, 2008. 
RECKNAGEL, R.O. Carbon tetrachloride hepatotoxicity. Pharmacol. Rev., v.19, n.2, p.145-208, 1967.

RIGUERA, R. Isolating bioactive compounds from marine organisms. J. Mar. Biotechnol., v.5, n.4, p.187-193, 1997.

SACHS, G.; SHIN, J.M.; VAGIN, O.; MUNSON, K.; WEEKS, D.; SCOTT, D.R.; VOLAND, P. Current trends in the treatment of upper gastrointestinal disease. Best Pract. Res. Clin. Gastroenterol., v.16, n.6, p.835-849, 2002.

SAKAGAMI, Y.; WATANABE T.; HISAMITSU, A.; KAMIBAYSHI, T.; HONMA, K.; MANABE, H. Antiulcer substances from marine algae. In: HOPPE, H.A.; LEVRING, T. (Eds.). Marine algae in pharmaceutical science. v.1. Berlin: Walter de Gruyter, 1982. p.99-108.

SATHIVEL, A.; RAGHAVENDRAN, H.R.B.; DEVAKI, T. Hepatoprotective nature of seaweeds (Ulva lactucal Gracilaria edulis) against liver injury induced by D-Galactosamine/endotoxin in rats. Seaweed Res. Utiln., v.25, n.1-2, p.109-111, 2003.

SHAY, H.; KOMAROV, S.A.; FELS, S.S.; MORANZIL, D.; GRUENSTEIN, M.; SIPLET, H. A simple method for the uniform production of gastric ulceration in rat. Gastroenterology, v.5, n.1, p.43, 1945.

SHIBATA, H.; LIMURO, M.; UCHIDA, N.; KAWAMORI, T.; NAGAOKA, M.; UEYAMA, S.; HASHIMOTO, S.; YOKOKURA, T.; SUGIMURA, T.; WAKABAYASHI, K. Preventive effects of Cladosiphon fucoidan against Helicobacter pylori infection in Mongolian gerbils. Helicobacter, v.8, n.1, p.59-65, 2003.

SILVA, R.O.; DOS SANTOS, G.M.P.; NICOLAU, L.A.D.; LUCETTI, L.T.; SANTANA, A.P.M.; CHAVES, L.S.; BARROS, F.C.N.; FREITAS, A.L.P.; SOUZA, M.H.L.P.; MEDEIROS, J-V.R. Sulfated polysaaharide fraction from red algae Gracilaria caudata protects mice gut against ethanolinduced damage. Mar. Drugs, v.9, n.11, p.2188-2200, 2011.

SMIT, A.J. Medicinal and pharmaceutical uses of seaweed natural products: a review. J. Appl. Phycol., v.16, n.4, p.245-262, 2004.

SOUZA, B.W.; CERQUEIRA, M.A.; MARTINS, J.T.; QUINTAS, M.A.; FERREIRA, A.C.; TEIXEIRA, J.A.; VICENTE, A.A. Antioxidant potential of two red seaweeds from the Brazilian coasts. J. Agric. Food Chem., v.59, n.10, p.5589-5594, 2011.
SUZIKI, Y.; HAYACHI, M.; ITO, M.; YAMAGANI, T. Antiulcer effect of cetraxate on various experimental gastric ulcer in rat. Jpn. J. Pharmacol., v.26, n.4, p.471-480, 1976.

SUZUKI, M.; KUROSAWA, E. Halogenated sesquiterpene phenols and ethers from the red alga Laurencia glandulifera Kutzing. Bull. Chem. Soc. Jpn., v.52, n.11, p.3349-3351, 1979

THOMAS, N.V.; KIM, S.K. Potential pharmacological applications of polyphenolic derivatives from marine brown algae. Environ. Toxicol. Pharmacol., v.32,n.3, p.325-35, 2011.

TRONO JR., G.C. Diversity of the seaweed flora of the Philippines and its utilization. Hydrobiologia, v.398/399, p.1-6, 1999.

VASANTHI, H.R.; SALI, V.K.; JASWANTH, A.; RAJAMANICKAM, G.V. Evaluation of anti gastric ulcer activities of four Gracilaria species from southeast coast of India in albino rats. Seaweed Res. Utiln., v.34, n.1/2, p.92-99, 2012.

VIJAYABASKAR, P.; SHIYAMALA, V. Antibacterial activities of brown marine algae (Sargassum wightii and Turbinaria ornata) from the Gulf of mannar biosphere reserve. Adv. Biol. Res., v.5, n.2, p.99-102, 2011.

VIJAYAVEL, K.; MARTINEZ, J.A. In vitro antioxidant and antimicrobial activities of two Hawaiian marine Limu: Ulva fasciata (Chlorophyta) and Gracilaria salicornia (Rhodophyta). J. Med. Food, v.13, n.6, p.1494-1499, 2010.

WONG, C.K.; OOI, V.E.; ANG, P.O. Protective effects of seaweeds against liver injury caused by carbon tetrachloride in rats. Chemosphere, v.41, n.1-2, p.173-176, 2000.

YANGTHONG, M.; HUTADILOK-TOWATANA, N.; PHROMKUNTHONG, W. Antioxidant activities of four edible seaweeds from the southern coast of Thailand. Plant Foods Hum. Nutr., v.64, n.3, p.218-223, 2009.

ZUBIA, M.; PAYRI, C.; DESLANDES, E. Alginate, mannitol, phenolic compounds and biological activities of two range-extending brown algae, Sargassum mangarevense and Turbinaria ornata (Phaeophyta: Fucales), from Tahiti (French Polynesia). J. Appl. Phycol., v.20, n.6, p.10331043, 2008.

Received for publication on $13^{\text {rd }}$ July 2012 Accepted for publication on $24^{\text {th }}$ Mach 2013 